\title{
LAW LIBRARIAN APPOINTED TO A JUDICIAL POSITION
}

In April 1980, Leone Carmel Glynn, Librarian of the New South Wales Supreme Court in Australia, was appointed a Justice of the New South Wales Industrial Commission. Justice Glynn is the first woman attaining a judicial post with the status of a Supreme Court judge in New South Wales.

With a B.A. from the University of Sydney and M.L.S. from the Columbia University, Justice Glynn qualified in law through the New South Wales Barristers Admission Board. She was admitted to the bar in 1964. Holding a Registration Certificate of the Library Association of Australia, she was the librarian of the New South Wales Supreme Court from 1954 to 1976 . Thereafter, until her recent judicial elevation, she was a Conciliation Commissioner.

\author{
Rob Brian \\ University of New South Wales, Australia
}

\section{BOOK PIRACY}

Book piracy has become a big international business. It is estimated that on a worldwide basis it deprives legitimate publishers of more than U.S. $\$ 1$ billion a year in sales. Most of the illegal reprinting takes place in countries like India, Pakistan and the Philippines which, though they are parties to the international copyright conventions, cannot enforce them effectively or in such states outside the conventions as Indonesia, Malaysia, Singapore, South Korea and Taiwan. From an economic standpoint the illegal reprinting is made possible through the availability of a cheap and increasingly more versatile photocopying machinery.

The International Publishers Association (IPA) has recently published two brochures on the illegal reproduction of books. "Piracy I" was prepared by the Secretary General of IPA. "Piracy II" is a special issue of the STM Newsletter (the International Group of Scientific, Technical and Medical Publishers). For further information and free copies of these publications write to: STM, Keizergracht 462, 1016 G E Amsterdam, The Netherlands.

\section{LEGAL PUBLICATIONS IN NORTHERN IRELAND}

A novel attempt to solve the problem of providing an adequate legal literature for a small jurisdiction has just begun to get under way in 